\title{
Value Pluralism and Consistency Maximization in the Writings of Aldo Leopold: Moving Beyond Callicott's Interpretations of the Land Ethic (Forthcoming in Environmental Values)
}

\section{BEN DIXON}

Stephen F. Austin State University

P.O. Box 6082, SFA Station

Nacogdoches, TX 75962-6082, USA

Email: bendixon04@gmail.com

\begin{abstract}
The $70^{\text {th }}$ anniversary of Aldo Leopold's A Sand County Almanac (1949) approaches. For philosophers - environmental ethicists in particular - this text has been highly influential, especially the 'Land Ethic' essay contained therein. Given philosophers' acumen for identifying and critiquing arguments, one might reasonably think a firm grasp of Leopold's ideas to have emerged from such attention. I argue that this is not the case. Specifically, Leopold's main interpreter and systematiser, philosopher J. Baird Callicott, has shoehorned Aldo Leopold's ideas into differing monistic moral theories that ill-serve a proper understanding. Against Callicott, my paper argues that Aldo Leopold embraces a robust moral pluralism, one that goes beyond mere pragmatics, and he does so while seeking a consistency maximisation of values. A new, improved understanding of Leopold's ideas thus emerges.
\end{abstract}

KEY WORDS: Aldo Leopold, Land Ethic, J. Baird Callicott, moral pluralism, environmental ethics

\section{INTRODUCTION}

In Aldo Leopold's 'Land Ethic' essay, he claims that no significant change in ethics has ever been made without persons internally altering their 'intellectual emphasis, loyalties, affections, and convictions.' He further points out that ethically broadening the notion of community to include nonhuman nature was not something the conservation movement of his day was emphasising. This is evidenced, Leopold surmises, by the 
absence of conservation-talk in both philosophy and religion circles. ${ }^{1}$ Much of his $A$ Sand County Almanac, the work in which 'The Land Ethic' essay is found, seeks to persuade the conservationist, the philosopher, and the religionist that a more expansive notion of community is warranted. Intriguingly, Leopold appeals to multiple norms of which he assumes his readers are already familiar and presumably theretofore sympathetic. Additionally, Leopold likens the moral changes he advocates to the practice of conservation itself. Doing so implies that just as with sacrificial conservation practices, moral conflict that includes a land ethic will surely arise, and its resolution is neither neat nor easy. When these elements are kept in mind and interpreted correctly, a very different understanding of Leopold's ethics emerges than is typically proffered.

This essay argues that Leopold intellectually commits himself to value pluralism and to a consistency maximisation of values, entailing that both these elements need to be present within any understanding of a land ethic properly deemed Leopoldian. Such an understanding of Leopold's ethics stands in strong contrast to two of the most famous interpretations put forward by J. Baird Callicott. The paper unfolds by first explaining Callicott's two differing takes on Leopold, showing some of the severe difficulties attending them, difficulties that directly stem from not taking into account the rather radical pluralism and consistency maximisation strategies for which I will argue. This, in turn, allows for putting forward the beginnings of an original and more accurate account of Leopold, one centering on both pluralism and ethical decision procedures incorporating such pluralism.

Moreover, as will be seen, Leopold's reasons for doing so hearken to more than just a pragmatic pluralism, which has been a point of contention between another

\footnotetext{
${ }^{1}$ Leopold 1949, p. 210.
} 
environmental philosopher, Bryan Norton, an advocate of Leopold embracing such pragmatism, and Callicott, who sees Leopold eschewing pragmatism. ${ }^{2}$ My arguments imply that Leopold's investment in pluralism goes much deeper than their debate allows. This depth of commitment by Leopold reveals itself pretty much through a straightforward reading of Leopold's ideas in light of a basic understanding of moral theory. However, Callicott's more entangled interpretations, the latter of which is still operative in his moral thinking — as evidenced by his latest book, Thinking Like a Planet: The Land Ethic and the Earth Ethic (2013) — very much set the terms for how Leopold's ideas would largely be received and how they are still understood today. It is to these seminal interpretations and to some conceptual disentangling that the paper now turns.

\section{CALLICOTT'S PRIORITISATIONS OF THE LAND ETHIC}

One ought not underestimate J. Baird Callicott's continuing scholarly importance. His ideas are still a keystone for how many interpret Leopold. For example, Roberta L. Millstein, in her own recent reexamination of Callicott's later take on Leopold, challenges Callicott's contention that Darwin's The Descent of Man had supreme influence over Leopold's ethical thinking. Though she argues Callicott's reading to be flawed, she admits it is now 'the canonical interpretation', influencing how many other philosophers come to understand Leopold's ideas. ${ }^{3}$ Attesting to Callicott's even broader historical influence on environmental philosophy, Wayne Ouderkirk writes the following:

J. Baird Callicott has been, and continues to be, one of the central figures in the development of environmental philosophy. To say that he has helped set the terms of the discussion, that he has developed one of the

\footnotetext{
${ }^{2}$ For a sampling of this debate, see Callicott, Grove-Fanning, Rowland, Baskind, French and Walker, 2009. Also Norton 2011.

${ }^{3}$ Millstein 2015, p. 1.
} 
central theoretical models in the field, the land ethic, and that his work has provoked reactions and reflections that have both clarified other models and opened new avenues for continued work is no exaggeration. [...] one cannot discuss [environmental ethics] without considering Callicott's views. And the reverse is also true: If one wants to examine Callicott's views, there is no escaping a discussion of the larger field. He is that important a figure. ${ }^{4}$

Echoes of the above characterisation are found in Melissa Clarke's review of Callicott's latest book, wherein she identifies him continuing to be a 'renowned leader' within environmental ethics, further assessing Callicott's recent tome, which includes the later interpretation of Leopold that I will criticise here, as making an 'invaluable contribution' to the field. Alan Holland's review of the same book heaps almost identical praise regarding Callicott's continuing relevance and influence. ${ }^{5}$

\section{Callicott's Early Interpretation of Leopold}

One of Callicott's earliest efforts at explaining Leopold's ideas is found in his controversial essay, 'Animal Liberation: A Triangular Affair'. 6 Gary Varner once claimed that, excluding Leopold's own essay, 'The Land Ethic', it is likely that no other environmental ethics piece is as widely reprinted as Callicott's 'A Triangular Affair'. Callicott begins his 'A Triangular Affair' essay by proposing that Leopold's land ethic is paradigmatic for what an environmental ethic amounts to ${ }^{8}$ citing especially Leopold's

\footnotetext{
${ }^{4}$ Wayne Ouderkirk, 'Introduction', in Land, Value, Community, 2002 p. 1.

${ }^{5}$ Melissa Clarke 2014, p. 368. Alan Holland is similarly praiseworthy. Calling Callicott an 'unmistakable and invaluable voice', Holland explains that Callicott's new book reaffirms this characterisation. See Holland, 2016.

${ }^{6}$ Callicott 1995, pp. 237-254.

${ }^{7}$ Gary Varner 2003, p. 196.

${ }^{8}$ Callicott 1995, p. 237.
} 
efforts to extend 'direct moral considerability from people to nonhuman natural entities' (i.e., Leopold urges that non-human nature is not simply a bundle of resources to be used instrumentally). ${ }^{9}$ Callicott implies that, ultimately, a land ethic identifies the locus of supreme moral value as residing within biotic wholes (i.e., ecosystems), not within any individual type of organism, human or otherwise. ${ }^{10}$

Callicott explains that such an interpretation of Leopold's land ethic can differentiate environmental ethics from animal rights/animal liberation movements, the latter of which Callicott labels 'humane moralism'. Hence, the seemingly related intellectual trend of assigning intrinsic value to animals is actually, Callicott thinks, part of a moral world view that is as distinct from an environmental ethic as humane moralism is from an anthropocentric ethic. Just as anthropocentric ethics underwrite the moral permissibility of sacrificing non-human animals to the desires and interests of humans (thus separating anthropocentric ethics from the animal-respecting upshot of humane moralism), so too does the holism characteristic of an environmental ethic buttress the notion that the needs of animals may be sacrificed for the good of, say, ecosystems (thus separating humane moralism from an environmental ethic). ${ }^{11}$ Callicott's emphasis on the schism between humane moralists and environmental ethicists is but one of his controversial claims; indeed, it is an aspect whose efficacy, as Louis Pojman pointed out, 'played an important historic role in separating animal rights from environmentalism. ${ }^{12}$

Callicott's trichotomising of environmental ethics, humane moralism, and anthropocentric ethics, was motivated - again — by a particular interpretation of Leopold.

\footnotetext{
${ }^{9}$ Ibid., p. 238.

${ }^{10}$ Ibid., p. 249.

${ }^{11}$ Ibid., pp. 238-239.

12 Pojman 2001, p. 51.
} 
And, at the outset, it is from Callicott's early interpretation of Leopold that I wish to begin distinguishing my own efforts at understanding Leopold.

To get at the specifics of Callicott's earliest take on Leopold, it is valuable first to take note of Callicott's idea that what separates Leopold's land ethic from both anthropocentric ethics and humane moralism is embracing exclusively a holistic worldview, a perspective nurtured and made reasonable, Callicott expains, by the science of ecology. Remarking on how ecology provides this new perspective, he writes that 'ecology focuses upon the relationships between and among things [...],' and prior to ecology's emergence as a science, 'the landscape appeared to be [.. . ] a collection of objects, some of them alive, some conscious, but all the same, an aggregate, a plurality of separate individuals. ${ }^{, 13}$

Callicott thinks it understandable that the earlier atomistic perspective yielded the notion that morality involves adjudicating between the rights and interests of individuals. Yet, ecology's ability to unify these atoms into a much larger whole, analogous to the second-order wholes wrought, for example, by cells making-up plant and animal bodies, changes things, morally, as a 'third-order whole' is made intelligible. Callicott explains that Leopold himself sometimes characterised this emerged third-order entity as an organic being. Other times, as Callicott clarifies, Leopold identifies this emerged entity as a community. That is, Leopold thinks that something very much like a community also arises given the economic dependencies between various organisms making-up a biotic whole, such dependencies yielding unique characteristics attributable only to an emerged system, a community of sorts. ${ }^{14}$

\footnotetext{
${ }^{13}$ Callicott, 1995, p. 241.

${ }^{14}$ Ibid., pp. 241-242.
} 
Leopold's land ethic and its attempt to extend moral consideration to the land, where the land is conceived of as either an organism or a community, become reasonable, Callicott further explains, by piggybacking on a number of already privileged ideas, including the notion that amongst the variety of human moral duties is self preservation, or what he thinks is the same thing, preserving one's own 'organic integrity'. Callicott continues this line of thinking about preserving organic integrities, writing:

It is not uncommon in historical moral theory, further, to find that in addition to those peculiar responsibilities we have in relation both to ourselves and other persons severally, we also have a duty to behave in ways that do not harm the fabric of society per se. The land ethic, in similar fashion, calls our attention to the recently discovered integrity - in other words, the unity—of the biota and posits duties binding upon moral agents in relation to that whole. Whatever the strictly formal logical connections between the concept of a social community and moral responsibility, there appears to be a strong psychological bond between that idea and conscience. ${ }^{15}$

Callicott thus concludes that Leopold's representation of the land as either a community or as a super-organism is adequate to stir feelings of conscience, the likes of which humans already experience toward persons or communities, or in Callicott's words, 'in relation to delicately complex, functioning social and organic systems. ${ }^{16}$ It is the supposed supremacy of the moral value that humans can perceive within biotic wholes that really distinguishes Callicott's earliest interpretation of Leopold's land

\footnotetext{
${ }^{15}$ Ibid., p. 242.

${ }^{16}$ Ibid.
} 
ethic. Callicott even draws from the history of philosophy to demonstrate that highlighting a whole's moral supremacy is not novel. In so doing, Callicott turns to none other than Plato and his idea that, 'body, soul, and society have similar structures and corresponding virtues. The goodness of each is a function of its structure or organization and the relative value of its parts or contribution made to the integrity, stability, and beauty of each whole.' So, just as Plato-in the interest of those wholes denoted by body, soul, or community — thinks it appropriate to sometimes sacrifice their constituent parts in order to preserve the various virtues of these wholes, similarly, Callicott maintains that the holism of the land ethic may require sacrificing, for example, the desires, interests, and, yes, even the lives of some humans and other animals to preserve the virtues of the biotic community—namely, its integrity, stability, and beauty. ${ }^{17}$

\section{Criticisms of Callicott's Early Interpretation of Leopold}

Callicott's early interpretation of Leopold, which supremely privileges biotic wholes, is the kind of monolithic idea sure to provoke strong reaction. Indeed, his invocation of Plato's idea that, at times, the good of the whole requires shepherding, disciplining, or flat-out eliminating any constituent part perceived as conflicting with that whole's good, almost guaranteed that this explanation of Leopold would meet with stinging criticism. Already, some thirty years prior, the noted thinker Karl R. Popper had forcefully argued that philosophers' idealisation of Plato clearly needs limits, citing specifically the totalitarian and anti-humanitarian nature of Plato's moral and political thoughts. ${ }^{18}$ Of course, it is these seemingly disquieting aspects of Plato's moral and political ideas that Callicott uses to make initial sense of Leopold's land ethic. And like

\footnotetext{
${ }^{17}$ Ibid., p. 245.

${ }^{18}$ Popper 1963.
} 
Popper's critique of Plato, some of the more biting criticisms against a Callicottian interpretation of Leopold aim squarely at Leopold's supposed willingness to sacrifice so much in the name of holism.

In his 1983 book, The Case for Animal Rights, Tom Regan charges that the land ethic amounts to 'environmental fascism'. To demonstrate such fascism, Regan imagines a case where a choice must be made either to destroy, say, a rare wildflower or a human being. The clear choice, according to Regan's understanding of the land ethic, is to do away with the member of the more plentiful, less contributory species - namely, the human being. That is, assuming the wildflower's rarity contributes more to the integrity, stability, and beauty of the biotic community than does some human, the land ethic clearly endorses sacrificing the human in a case of mortal conflict. ${ }^{19}$ Given Regan's own arguments that moral rights accrue only to sentient individuals (e.g., humans and other higher animals), his use of the term 'ecofascism' to denote the implications of Leopold's imputed holism becomes understandable. Therefore, it is clear that Regan considers the land ethic as leading to a reductio ad absurdum and, consequently, rejects it.

Elliot Sober is similarly critical of morally privileging wholes. Sober writes: 'It is hard to know what to say to someone who would save a mosquito, just because it is rare, rather than a human being, if there were a choice.' Sober suggests that, to most, the assumptions behind the land ethic are so alien, that they preclude its acceptance. ${ }^{20}$

Obviously the fascism charge being levied against Leopold by Regan and Sober is correct, if it is the case that Leopold's land ethic entails an ecological holism

\footnotetext{
${ }^{19}$ Regan 1983, pp. 361-362.

${ }^{20}$ Sober 2003, p. 305.
} 
exclusionary of other moral concerns. To be sure, 'A Triangular Affair' is Callicott's argument for such exclusivity as the appropriate interpretation of Leopold's land ethic.

In contrast, my forthcoming assessment of Leopold entails that land holism is not to be invariably privileged over other moral concerns, because Leopold applies a number of values both to individuals and to groups, and he touts a consistency maximisation of those values in their real-world realisation. That is to say, Leopold's writings, evidencing, as they do, a respect for values inclusive of utility, virtue, and even moral agency, also demonstrate a concern that actions taken on behalf of these values do not come at each other's expense, or if so, that a reconciliation of these values should be forthcoming. Consequently, Regan's and Sober's indictment of the land ethic as being fascistic is wrongheaded, as is Callicott's early interpretation of Leopold which supports such a skewed hierarchical view.

To preview my take on Leopold's moral views, consider an earlier statement by Leopold about 'true conservation', one that I will later argue is still operative in A Sand County Almanac. In 1939 Leopold writes: 'When land does well for its owner, and the owner does well by his land; when both end up better by reason of their partnership, we have conservation. When one or the other grows poorer, we do not. ${ }^{21}$ Yet, the land ethic principle found in the later Sand County Almanac (i.e., 'A thing is right when it tends to preserve the integrity, stability, and beauty of the biotic community. It is wrong when it tends otherwise. ${ }^{, 22}$ ) — exists to guide right-minded conservation. It would be surprising if Leopold's views morphed into a land ethic that would fascistically shove aside concerns for, say, human well-being when the well-being of the conservation-

\footnotetext{
${ }^{21}$ Aldo Leopold, 'The Farmer as a Conservationist', American Forests 45, 6 (June 1939), p. 238; quoted. in Meine 1988, p. 388.

${ }^{22}$ Leopold 1949, p. 224-225.
} 
minded farmer is clearly a part of Leopold's equation for right-minded conservation. More on this later.

For a number of reasons, including perhaps sensitivity to the charge of ecofascism, Callicott backed away from his earlier interpretation of Leopold. The clearest reason for this change, however, relates to Callicott's evolved conviction that the conceptual roots of Leopold's land ethic, upon investigation, are traceable through an ethical tradition that includes the likes of naturalist Charles Darwin and philosopher David Hume. As will be seen, situating the land ethic within this tradition supposedly has very different consequences from drawing parallels between the land ethic and Plato's moral and political thoughts. ${ }^{23}$

\section{Callicott's Later Interpretation of Leopold}

In Callicott's later essay, 'The Conceptual Foundations of the Land Ethic', ${ }^{24}$ he argues that several pregnant statements by Leopold evidence the Darwinian influence in Leopold's thought. For example, Leopold claims that extending ethics to previously excluded entities and activities is part of 'ecological evolution'. Callicott thinks that the key thing to be taken away here is that ethics can be discussed in biological terms. Furthermore, Leopold states that an ethic is 'a limitation on freedom of action in the struggle for existence.' This last assertion, argues Callicott, 'unmistakably calls to mind Darwinian evolution as the conceptual context in which a biological account of the origin and development of ethics must ultimately be located.' So, because Leopold seems to define ethics and their extension naturalistically, and because he uses language

\footnotetext{
${ }^{23}$ Callicott responds to the divisiveness of his views in two important pieces. Each takes advantage of his theoretical switch to a neo-Humean ethical worldview, both in general and with specific reference to interpreting Leopold. See Callicott 1989 and Callicott 1998.

${ }^{24}$ Callicott 1987.
} 
hearkening to evolutionary theory, his moral thinking must be substantially Darwinian. ${ }^{25}$ Callicott then prods his readers down a path that leads back to an ethical tradition which, while not explicitly endorsed by Leopold, influenced Darwin, and thus should be recognised as the land ethic's theoretical framework.

Explaining how Darwin sought after an account of ethics complementary to his revolutionary biological views, Callicott argues that Darwin embraced the work of the 'moral sense theorists', those who argue that ethics are the product of sentiments or feelings. Indeed, unlike many earlier philosophers who argued that ethics are derivable from reason, these moral-sense theorists (e.g., David Hume and Adam Smith) proposed a lesser role for reason, namely, as amplifier and informer of sentiments. ${ }^{26}$

Taking cues from the moral sense theorists, Darwin surmises that morality originates in parental and filial affections, cultivating close-knit social groups amongst kin. These feelings might then attach themselves to extended family, enlarging the social group. But if such enlargement betters its members' life prospects (e.g., through better defense or better provisioning), this might increase the probability of passing down genes inclining such pro-social behaviors. 'Thus, the more diffuse familial affections, which Darwin (echoing Hume and Smith) calls the "social sentiments," would be spread throughout a population. ${ }^{27}$

Callicott goes on to suggest that Leopold's status as a natural historian made him heir to this 'protosociobiological perspective on ethical phenomena'. Indeed, Callicott tries to further demonstrate the Darwinian nature of Leopold's thought by stringing together two separate quotations from Leopold that hearken to the natural evolution of

\footnotetext{
${ }^{25}$ Ibid., pp. 188-189.

${ }^{26}$ Ibid., p. 190.

${ }^{27}$ Ibid., pp. 190-191.
} 
ethics: 'Since "the thing [ethics] has its origin in the tendency of interdependent individuals or groups to evolve modes of cooperation,... all ethics so far evolved rest upon a single premise: that the individual is a member of a community of interdependent parts." (For purposes that will become clear, it is important to note that the first half of the quotation is part of a larger paragraph not cited by Callicott, one wherein Leopold goes on to cite economics as having ethical content, something that Callicott resists for reasons also to be explained momentarily.) These meshed quotations punctuate, Callicott maintains, Leopold's Darwinian-inspired conviction that ethics correlate with community. In fact, if Leopold (following Darwin) is correct about this connection between ethics and community, then Callicott thinks it serves as an analytical tool, not only for understanding the natural history of morality, but for identifying how morality will progress in the future, with all its attending precepts, prescriptions, and proscriptions in tow. Of course, it is based upon this naturalistic interpretation of moral history's past, present, and future from which Callicott thinks Leopold derives his land ethic. ${ }^{28}$

Supposedly operative in Leopold's thinking, then, is Darwin's idea that as humans unite themselves into ever-larger communities, sympathies are extended. Darwin also thinks 'the simplest reason' eventually informs persons to expand their social instincts toward those complete strangers with whom nationhood unites them, persons thereafter only needing to overcome 'artificial barriers' to embrace all of humanity. The land ethic, consequently, represents a further inclusion along these lines: the addition of the biotic community. Callicott cites the following quotation from Leopold as proof that

\footnotetext{
${ }^{28}$ Ibid., pp. 191-192.
} 
Leopold thought like this: 'The land ethic simply enlarges the boundary of the community to include soil, waters, plants, and animals, or collectively: the land. ${ }^{29}$

As with his early exposition of Leopold in 'A Triangular Affair', Callicott again highlights Leopold's judgment that ecology makes thinking of the land as a community intelligible (this idea having been developed in the 1920s by English biologist, Charles Elton). But whereas Callicott earlier acknowledges instances wherein Leopold alternatively, albeit 'less consistently', characterises the land as an organism-in the later 'Conceptual Foundations', he limits Leopold's considered view to the Eltonian ecosystem-as-community analogy, there arguing that the organism model is only 'vestigially present' in Leopold's land ethic. Callicott reasons that Leopold probably saw the community analogy as more apt, because Leopold recognised the organism view as marginal amongst ecologists. Moreover, Callicott thinks the community view better fits the Darwinian/Humean framework in which Leopold supposedly situated his ideas. ${ }^{30}$ As a brief but important aside, it is noteworthy that Callicott's new book again changes his (Callicott's) interpretation of how Leopold treats the organism model in the latter's mature thinking, including within his $A$ Sand County Almanac. What was supposedly 'vestigial' in Leopold's writings is now, by Callicott's estimation, evidence of Leopold having 'intuitively' realised how ecosystem ecology would eventually develop to embrace multiple metaphors. ${ }^{31}$ Specifically, Callicott's new book argues that Leopold's use of mixed-metaphors to characterise ecosystems, including those of 'community,' 'mechanism,' and 'super-organism,' are all now apt, given how the science

\footnotetext{
${ }^{29}$ Ibid., p. 193.

${ }^{30}$ Ibid., pp. 194-202.

${ }^{31}$ Callicott 2013, p. 89.
} 
of ecology has evolved. ${ }^{32}$ This is super-convenient, too, as Callicott goes on to use the 'super-organism' metaphor to buttress his new, Leopoldian-inspired Earth Ethic. The Earth Ethic is informed by an older essay of Leopold's, 'Some Fundamentals of Conservation in the Southwest', which itself very much privileges the organism metaphor. ${ }^{33}$ Consequently, Callicott can now espouse the following: there is continuity in Leopold's own thinking regarding ecosystems (and the metaphors operative therein); Leopold's position is born out by contemporary science given Hierarchy Theory, which utilises the aforementioned metaphors; ${ }^{34}$ and lastly, again by virtue of this switch, Callicott can more consistently join the Land Ethic to his new 'Leopoldian' Earth Ethic. Still, Callicott contends within his 'Conceptual Foundations' essay that it is actually the inculcation of the land-as-community idea that will ultimately sway persons to embrace the land ethic proper (i.e., the land ethic will be accepted because of 'ecology's social representation of nature', coupled with the notion that we as biotic community members are capable of hurting other non-human community members, as well as harming the overall biotic community). Darwinism via Hume and Smith predicts the possibility for such an expansion of sentiments, and Leopold-Callicott surmisesdoes everything possible in A Sand County Almanac to tout such an expansion of feeling. Callicott further suggests that a Copernican understanding of the universe, which, in part, situates the earth in a vast, hostile universe, subconsciously facilitates the idea of an interdependent, life-giving/sustaining community on Earth. Callicott allows that Leopold never directly acknowledges this consequence of the Copernican view, but Callicott

\footnotetext{
${ }^{32}$ Ibid., pp. 86-91.

${ }^{33}$ Ibid., pp. 198-200.

${ }^{34}$ Ibid., pp. 41-44.
} 
nevertheless does assign this perspective a role when identifying the conceptual foundations of the land ethic. ${ }^{35}$

As said at the outset of discussing Callicott's revised interpretation of Leopold, situating the land ethic within the moral sense tradition has very different consequences from drawing parallels between Leopold's land ethic and Plato's moral and political ideas. Specifically, the moral sense tradition entails ideas that seemingly require Callicott to jettison interpretive elements favorable to the Plato analogy, and consequently, to the ecofascism charge hounding his earlier understanding of Leopold. This is because the Darwinian biosocial roots of ethics, Callicott urges, provide some resistance to favoring objects of later evolutionary ethical development over earlier ones.

A hierarchical ordering of moral priorities emerges, with the land ethic being the most recent addition and, consequently, wielding the least amount of influence. A supposed upshot of this is that persons, unlike in Plato's ideal state or Callicott's heretofore ideal biosphere, will not invariably be sacrificed when their actions or interests conflict with the good of the whole. ${ }^{36}$ Callicott explains:

$[\ldots]$ as a general rule, the duties correlative to the inner social circles to which we belong [e.g., family] eclipse those correlative to the rings farther from the heartwood when conflicts arise [...] A zealous environmentalist who advocated visiting war, famine, or pestilence on human populations [. ..] in the name of the integrity, beauty, and stability of the biotic community would be $[\ldots]$ perverse. Family obligations in general come before nationalistic duties and humanitarian obligations in general come

\footnotetext{
${ }^{35}$ Callicott 1987, pp. 194-195.

${ }^{36}$ Ibid., pp. 206-207.
} 
before environmental duties. The land ethic, then, is not draconian or fascist. $^{37}$

Callicott makes clear, however, that a land ethic, despite its location on the moral periphery, can still exert some influence on human behavior. Just as obligations to one's nation may come at the expense of his inner social circles (e.g., through paying taxes or serving in the military), so too nurturing the land's good may come at the expense of other, more typically privileged objects of one's moral concern. Callicott contends that Leopold's understanding of ecology, which identified the land's health as contingent upon normal rates of species extinction and the general tendency of evolution to enrich the land biologically through speciation, informs our moral sensibilities (and thus a land ethic) that the land should at times be considered as more important than the individual good of one or more of its parts. ${ }^{38}$ Hence, the moral good emerging from the land-ascommunity idea, a good arising from those characteristically enduring and evolving relationships amongst the community's constituent organisms, gives way to a series of behavioral constraints, which Callicott identifies as consistent with Leopold's thinking. As if descending from a mountaintop visit with Leopold, Callicott proclaims: According to the land ethic, therefore: Thou shalt not extirpate or render species extinct; thou shalt exercise great caution in introducing exotic and domestic species into local ecosystems, in extracting energy from the soil and releasing it into the biota, and in damming or polluting water courses;

\footnotetext{
${ }^{37}$ Ibid., p. 208.

${ }^{38}$ Ibid., pp. 208-210.
} 
and thou shalt be especially solicitous of predatory birds and mammals.

Here in brief are the express moral precepts of the land ethic. ${ }^{39}$

After laying-out his revised interpretation of Leopold, Callicott deliberates over whether the land ethic is to be understood deontologically (i.e., as duty based, where the land ethic assigns moral standing to nature along with correlative duties to humans) or as prudential (i.e., the land ethic represents enlightened self-interest for the human community). In favor of a deontological rather than a prudential understanding, Callicott not only reiterates that the land ethic's conceptual foundations point toward duty, but he cites additional statements by Leopold, wherein Leopold rejects a prudence-only view of the land. Callicott reminds his readers that Leopold, when indicting as inadequate the conservation mindset of his day, explains that this mindset 'defines no right or wrong, assigns no obligation, calls for no sacrifice, implies no change in the current philosophy of values. In respect of land use, it urges only enlightened self-interest.' Callicott then goes on to identify other instances where Leopold uses morally weighty language dismissive of prudence-only conservation. ${ }^{40}$

There is tension, however, in Leopold's own account, because of other instances where, in Callicott's words: 'Leopold does frequently lapse into the language of (collective, long-range, human) self-interest.' Callicott cites, for example, Leopold's historical assessment that 'the conqueror role is eventually self-defeating', as it pertains to humans relating to the environment. Thus, surmises Callicott, Leopold appeals to something other than a new moral relationship with the land in arguing for revised conservation practices. Referencing another passage, Callicott shows where Leopold

\footnotetext{
${ }^{39}$ Ibid., p. 205.

${ }^{40}$ Ibid., p. 212.
} 
implies that preserving a rich diversity of organisms (where most of this diversity is of no economic value to humans) is crucial for maintaining the smaller percentage of life that is of economic value. Again, it appears as if Leopold is, at times, appealing to those instincts in humans that elsewhere he argues are woefully inadequate for right-minded conservation. Lastly, Callicott cites Leopold's explicit recognition that ethics can be understood as a way to meet new ecological situations, where the path to 'social expediency' is unclear to the individual. Ethics, in Leopold's words, are 'a kind of community instinct-in-the-making', which allow for successful navigation of new ecological situations. ${ }^{41}$ Consequently, Callicott's worry is that Leopold is inconsistent, using language indicative of both a concern for prudential conservation and conservation based on obligations to nature.

Callicott reconciles this apparent tension in Leopold by acknowledging differing perspectives from which the phenomena of ethics are viewable. That is, from an outside, scientific perspective, ethics are amenable to a sociobiological assessment, where they are understandable as contributory to biological fitness. Taking up this perspective can yield the kind of prudential talk in which Leopold sometimes engages. However, 'from the lived, felt point of view' of a community member affected by moral sensibilities, ethical phenomena are 'deontological'; ethical experiences alternatively give way to the kind of normative talk Leopold wants folks to start using toward the land-talk that is replete with notions of 'genuine love, respect, admiration, obligation, self-sacrifices, [and] conscience'. ${ }^{42}$

\footnotetext{
${ }^{41}$ Ibid., p. 213.

${ }^{42}$ Ibid., pp. 213-214.
} 


\section{Preparing to move beyond Callicott's Later Understanding of Leopold}

Regrettably, Callicott's later take on Leopold continues ignoring a crucial feature necessary for an appropriate understanding of the land ethic: the fact that Leopold sees the land ethic not as appropriately prioritised either ahead of or, as is mostly the case with Callicott's later understanding, behind other value considerations. Instead, Leopold sees the land ethic as appropriately integrated with other moral concerns, and this has a greater seismic shift for our moral thinking than Callicott's later understanding allows. Still, unlike with his earlier interpretation, Callicott does seem to acknowledge that Leopold's ideas entail a broader moral world-view in some respects.

Callicott's attempts at situating the land ethic within a rich Humean/Darwinian context allows for acknowledging a number of moral communities, because human moral sentiments evince appropriate positive attitudes toward more than one community. It is the process of moral sentiments bestowing significance on various moral communities, of course, that allows for Callicott seemingly to escape the ecofascism charge. A combination of natural selection and, supposedly, reason, on his account, synergistically yield a non-perverse, hierarchical ordering of moral communities. These orderings, then, will not entail invariably sacrificing humans and non-human animals for a greater biotic community. In fact, Callicott thinks a concern for land-holism rightly occupies the periphery of our moral concerns, although, at times, it exerts greater influence on humans, when humans possess appropriate ecological information. Somehow, according to Callicott, people will just know (feel?) when relevant ecological information is 
sufficient to motivate, emotionally, an occasional reversal of priorities not amounting to ecofascism.

I will argue that nowhere does Leopold put forward or imply the kind of hierarchical ordering of moral communities Callicott ascribes to him. Leopold does, however, advocate dissolution of value conflict and suggests that appropriate conservation involves being respectful of both human and non-human moral goods. These moral goods, it is important to stress, are also not simply reducible to the intrinsic value of moral communities. These points are demonstrable from what Leopold penned with his own hand.

Noteworthy, too, is that despite the broadened moral view entailed by the Humean/Smithean framework in which Callicott newly situates Leopold, Callicott cannot bring himself to acknowledge Leopold advocating prudential reasoning as providing normative incentive (though, not the sole incentive) for humans to embrace the land ethic. Recall that within the exposition of Callicott's later views, there was a description of his invocation of a dichotomy of ways Leopold chooses to discuss morality: a naturalistic, sociobiological way and a normative way. Callicott uses this distinction to reconcile tensions in Leopold's discussions of appropriate normative motivators for conservation.

Because Leopold states that a human-centered justification for conservation is not sufficient for a moral relationship with the land, and yet he goes on to use humancentered reasons for pro-land actions, Callicott sees a need to explain away this supposed conflict by means of the aforementioned naturalistic/normative distinction. Callicott contends that Leopold's naturalistic take on ethics endorses an amoral, but nevertheless 
enlightened, self-interested justification for the land ethic, and the normative take underwrites the moral reasons for justifying the land ethic. Clearly, Callicott fails to recognise a broader understanding of Leopold's ethics that also encompasses morally significant, human-centered reasons for embracing a land ethic.

\section{LEOPOLD'S PLURALISM AND HIS DECISION PROCEDURES}

I endeavor now to show how Leopold's writings embrace a plurality of values when discussing matters of moral import, with some of these values being humancentered. This involves a different strategy than Callicott employed and is still defending. That is, rather than relying, as Callicott does, on supposedly pregnant statements that indicate Leopold was not only Darwinian in his ethics, but allowing for, then, the further supposition that one should draw a direct line from Leopold to moral sense theorists like Hume and Smith—I, instead, look to what Leopold actually wrote in both $A$ Sand County Almanac and elsewhere. This provides a more accurate account of the man's ethics. ${ }^{43}$

As Callicott himself affirms, Leopold very much stresses a relationship between ecology and ethics. For not only is it the taking-up of the ecological point of view that helps determine the reasonableness of his land ethic (something that itself should count against Leopold being committed to a strong moral sense account of ethics; Hume's considered view, contextualised by his skepticism, was entirely dismissive of reason's efficacy to define moral goods) — but, as Callicott additionally points out, Leopold thinks that the very process of extending ethics to hitherto unregulated forms of conduct is a

\footnotetext{
${ }^{43}$ Holmes Rolston III is a philosopher very much inspired by Leopold and who goes on to argue for a pluralistic approach to environmental ethics, an approach that captures much of what Leopold himself values. See, for example, Rolston 2012. Rolston argues here that intrinsic moral value can be found in humans, individual non-human organisms, species, ecosystems, and the biosphere as a whole.
} 
'process in ecological evolution' (i.e., Leopold implies that this is a process wherein improved social interactions between entities betters their survival conditions). Leopold explains:

An ethic, ecologically, is a limitation on freedom of action in the struggle for existence. An ethic, philosophically, is a differentiation of social from anti-social conduct. These are two definitions of one thing. The thing has its origin in the tendency of interdependent individuals or groups to evolve modes of co-operation. The ecologist calls these symbioses. Politics and economics are advanced symbioses in which the original free-for-all competition has been replaced, in part, by co-operative mechanisms with an ethical content. ${ }^{44}$

This is the fuller version of the quotation previously highlighted where I noted Callicott's omitting part of it, specifically, the last sentence wherein Leopold identifies economics as a co-operative mechanism having ethical content; this will help later identify utility as having an ethical upshot for Leopold. However, more to the current point, further observe here Leopold suggesting that such co-operative mechanisms have become more complex as time passes. Leopold elaborates on this, suggesting that there has been moral progress as humans have moved from the simplicity of the Mosaic Decalogue to the involvedness of democracy. ${ }^{45}$ This notion of an emerging complexity characterising ethics is an important feature of Leopold's account, for he touts a naturalised explanation as to the origin of our ethical ideas. Ethics for Leopold, as explained above, have emerged from the development of symbioses, or what we might

\footnotetext{
${ }^{44}$ Leopold, 1949, p. 202.

${ }^{45}$ Ibid., p., 202-203
} 
today call 'mutualisms'. Norms evolve and persist when following them creates reciprocal value.

Despite the common origin of all ethics, this naturalised explanation as to the origin of ethics — when framed against the background of Leopold's overall thought— does not allow for a reduction of ethics to a single value scheme (e.g., Callicott's community memberships and the positive emotion-tickling humans ultimately will feel at the sight of well-functioning communities). Indeed, even when Leopold goes on to formally state his land ethic principle (which ties the morality of an action to its effects on the biotic community), the concern for environmental health underwriting this principle fits neither Callicott's early interpretation of ethical monolith nor his later, still privileged interpretation of it as a largely marginal consideration born of expanding sentiment. Rather, established ethics are made more complex by the addition of a new, important, holistic moral consideration - the objectively identifiable health of the land, be it analogised as organism-like or more akin to community health. ${ }^{46}$ Present in Leopold's writings, I will now show, is both recognition of this complexity in moral life and an emphasis on behavior respectful of a full variety of moral value in the world, the kind of variety his intended audience would recognise and to which Leopold himself commits.

To get at Leopold's pluralism, consider, for example, Leopold's contention that something very special arises regarding the moral status of us humans when we act in a morally correct manner. The following provocative quotation was written and publicly presented, according to Leopold's biographer, Curt Meine, just some sixteen months

\footnotetext{
${ }^{46}$ Elsewhere I argue that Leopold's valuational commitment to 'health' can be seen as underwriting ascriptions of intrinsic value to both biotic wholes and individual organisms; see Dixon 2016.
} 
prior to Leopold organising his 'Land Ethic' essay, ${ }^{47}$ and both are published in $A$ Sand County Almanac. It reads:

For one species to mourn the death of another is a new thing under the sun. The Cro-Magnon who slew the last mammoth thought only of steaks. The sportsman who shot the last [passenger] pigeon thought only of his prowess. The sailor who clubbed the last auk thought of nothing at all. But we, who have lost our pigeons, mourn the loss. Had the funeral been ours, the pigeons would hardly have mourned us. In this fact, rather than in Mr. Du Pont's nylons or Mr. Vannevar Bush's bombs, lies objective evidence of our superiority over the beasts. ${ }^{48}$

Moral agency, correctly exercised, is an ability that lifts humans above the constituents of nonhuman nature, or so Leopold thinks here. ${ }^{49}$ Realising the horror of anthropogenic extinction, and internalising it such that we mourn the loss, is an exercise of this capacity. Its use speaks well for us humans, albeit a bit ironically here, it must be admitted, given our role in the passenger pigeon's demise. Leopold implies that other organisms cannot realise either the concept or the magnitude of our world losing another species. We humans can and should (and have, at least some of us). The reason for this advanced status is a capability that comes from being rational enough to be this moral; it is not a judgment about an advanced moral status derivable from evolutionary-ordered,

\footnotetext{
${ }^{47}$ Meine explains that Leopold made the remarks that follow, and which would end up in $A$ Sand County Almanac under the subsection 'On a Monument to the Pigeon', on April 6, 1946 (Meine, p., 482). Leopold began organising the material that became 'The Land Ethic' essay in July 1947 (Meine, p., 501).

${ }^{48}$ Leopold, A Sand County Almanac p., 110

${ }^{49}$ Even if, as Callicott argues, one should tie Leopold's ideas substantially to Darwin's own, there are ideas within the latter's writings regarding 'conscience' and the related idea of moral agency that can be used to carve-out a unique dignity for humans, one that I argue is contingent upon respect for nonhuman constituents of the environment and which is different that what Callicott's interpretation of Darwin allows; see Dixon 2007.
} 
community membership simpliciter, as Callicott must maintain. Indeed, emphasising a special moral status for humans based on our ability to be moral, or perhaps better put, based on our ability to be moral in a particular way, is more reminiscent of the Kantian ethical tradition rather than the Humean/Smithean, moral sense one.

Careful readers of Leopold also realise that he assigns moral import not only to the biotic community via the 'Land Ethic', and to human moral agency, as illustrated above, but also to the individual character of humans. Of course, the idea that character ought to be seen as morally significant is, as Callicott notes in his earlier interpretation of Leopold, an idea dating back, in the Western philosophical tradition, to the Ancient period, where philosophers like Plato and Aristotle deliberated on '[ . . ] the sorts of qualities of character it is morally praiseworthy to acquire and maintain.' Historically, these qualities of character are labeled 'virtues'. 50

With respect to the virtues of humans, Leopold's biographer, Curt Meine, certainly implies that these are of deep concern to Leopold. Of particular importance to him, Meine indicates, is for an individual person to possess a correct disposition toward the land. Remarking on Leopold's commitment to individualistic thinking generally, Meine writes: 'Although Leopold expressed his devotion to individualism only on rare occasions, it was fundamental to his thinking. He was in many respects an enlightenment personality confronting the realities of the twentieth-century world [...]'. As evidence of this last idea, Meine cites an essay of Leopold's in which Leopold bemoans conservation's over-dependency on 'the current doctrine of private profit and public subsidy’. Leopold writes:

\footnotetext{
${ }^{50}$ Timmons 2002, pp. 211-212.
} 
It [conservation] expects subsidies to do more- and the private owner to do less - for the community than they are capable of doing. We rationalise these defects as individualism, but they imply no real respect for the landowner as an individual. They merely condone the ecological ignorance which contrasts so strongly with his precocity in mechanical things. 51

But why is it important for an individual to be ecologically sophisticated, taking responsibility for his treatment of the land? Why not simply let the brain trust and influence of government set ecological standards and enforce them? After all, if the wellfunctioning of varying communities is solely what has intrinsic value, as Callicott maintains, it should not matter, morally, how that is achieved. To be sure, Leopold did think private conservation strategically necessary for the maintenance of ecosystemic health (i.e., conservation often works better when private persons are predisposed to thinking and acting ecologically on their own), but he also thought it was otherwise morally important for individuals to have an ethical relationship with the land, where this relationship reflects well upon the character of the individual, and where the value of having such a character serves as a motivator.

Meine further expands upon this. Quoting from an essay of Leopold's, wherein Leopold 'envisioned a future Wisconsin built along the farmer's own self-applied conservation standards', Meine cites the following wistful imaginings of Leopold's regarding the appearance of an ideal farm:

\footnotetext{
${ }^{51}$ Leopold, 'The Farmer as Conservationist', p., 316 quoted. in Curt Meine, Aldo Leopold: His Life and Work, p. 389.
} 
The creek banks are wooded and ungrazed. In the woods, young straight timber-bearing trees predominate, but there is also a sprinkling of hollowlimbed veterans left for the owls and squirrels, and of down logs left for the coons and fur-bearers. On the edge of the woods are a few widespreading hickories and walnuts for nutting. Many things are expected of this creek and its woods: cordwood, posts, and sawlogs; flood-control, fishing, and swimming; nuts and wildflowers; fur and feather. Should it fail to yield an owl-hoot or a mess of quail on demand, or a bunch of sweet William or a coon-hunt in season, the matter will be cause for injured pride and family scrutiny, like a check marked 'no funds. ${ }^{52}$

As Meine explains, Leopold thought conservation activities for the farmer ought to be, in Leopold's words, a 'positive exercise of skill and insight, not merely a negative exercise of abstinence or caution'. Meine further says that Leopold thought the farm to be 'the owner's portrait of himself. Conservation [Leopold continues] implies selfexpression in that landscape, rather than blind compliance with economic dogma, ${ }^{53}$

The last three quotations from Leopold carry two implications for present consideration: First, they evidence Leopold's commitment to the idea that persons ought to be ethically respected as individuals having certain capacities, not just as entities deriving moral value from community membership alone (this idea was also true with the above point about moral agency); second, they clarify a virtue that self-aware human beings should cultivate as a ground of self-respect, namely, right-minded ecological thinking. That a concern for self-respect is an appropriate motivator-and indeed that it

\footnotetext{
${ }^{52}$ Ibid.

${ }^{53}$ Ibid.
} 
is preferable, in ways, to external motivators-demonstrates Leopold's commitment to the notion that something like virtue is to be valued in itself. Thus, we see Leopold's commitment to yet another value besides land holism, the life of the self-respecting, virtuous individual.

Further textual evidence against the idea that Leopold's moral views are exclusively concerned with community membership can be found both in the passage just prior to Leopold's articulation of the land ethic principle in A Sand County Almanac and in that passage directly following it. First, regarding that which precedes the land ethic principle, Leopold writes: 'The "key-log" which must be moved to release the evolutionary process for an ethic is simply this: quit thinking about decent land-use as solely an economic problem. Examine each question in terms of what is ethically and esthetically right, as well as what is economically expedient. ${ }^{54}$ Notice this excerpt makes clear that Leopold deems it fitting for some human thinking to be economically oriented (i.e., for some human thinking to be utility-seeking) and for it to be environmentally holistic (i.e., what removing the 'key-log' implies). Interestingly, this utility-seeking behavior (i.e., seeking after what Leopold calls the 'economically expedient') is not simply amoral, as this last quotation from Leopold seems to indicate. Consider an earlier statement of Leopold's about expediency. He writes: An ethic may be regarded as a mode of guidance for meeting ecological situations so new or intricate, or involving such deferred reactions, that the path of social expediency is not discernible to the average individual. Animal instincts are modes of guidance for the individual in meeting such

\footnotetext{
${ }^{54}$ Leopold1949, p. 224. Emphasis mine.
} 
situations. Ethics are possibly a kind of a community instinct in-themaking. ${ }^{55}$

Here Leopold says that ethics can serve a precautionary function, increasing the probability that individuals acting ethically bring about what is socially advantageous or socially expedient. Conjoin this thought with Leopold's earlier claim that ethics just are a type of symbioses (i.e., ethics are concerned with facilitating mutually beneficial relationships) and one starts gaining confidence that Leopold's ethical views make room for expediency or utility sometimes being seen as an appropriate object of ethical behavior. Again, this is a different interpretation than Callicott gives of all this, where he argues that human-centered reasons for conservation dwell in an economic realm that is thoroughly amoral. It has always seemed curious that Callicott privileges this amoral understanding in his later interpretation if, as he has it, Leopold fits comfortably in a moral sentiments scheme that largely prioritises human well-being over other moral considerations. Economics should carry a thoroughly moral upshot for Leopold on his account.

The truth is that Leopold makes an identity claim that logically commits him to viewing expediency or utility as ethical. Moreover, recall the earlier quotation of Leopold's to which special attention was drawn. Leopold wrote: 'Politics and economics are advanced symbioses in which the original free-for-all competition has been replaced, in part, by co-operative mechanisms with an ethical content. ${ }^{56}$ Leopold flat-out states here that economics help replace free-for-all competition and is an advanced symbioses, a co-operative mechanism by virtue of its having ethical content, politics too.

\footnotetext{
${ }^{55}$ Ibid., p. 203.

${ }^{56}$ Ibid., p. 202.
} 
The point Leopold makes after expressing the land ethic principle also concerns expediency. He writes: 'It of course goes without saying that economic feasibility limits the tether of what can or cannot be done for land. It always has and it always will. ${ }^{57}$ Notice that Leopold is saying here that our actions are informed and constrained by the perceived human goods that fuel economies. Shortly after this passage, Leopold expresses a rather surprising thought regarding the appropriate scope for such expediency. Leopold reflectively notes:

For the first time in the history of the human species, two changes are now impending. One is the exhaustion of wilderness in the more habitable portions of the globe. The other is the world-wide hybridization of cultures through modern transport and industrialization. Neither can be prevented, and perhaps should not be, but the question arises whether, by some slight amelioration of the impending changes, certain values can be preserved that would otherwise be lost. ${ }^{58}$

After all that Leopold has written up to this point in A Sand County Almanac, it is noteworthy to see him not rejecting, wholesale, the morally permissibility for wilderness to exist alongside humans reasonably occupying, and thus modifying, the more habitable spots on earth. This revealing admission further instills confidence in the notion that land holism ought not to be the only appropriate normative motivator. Sometimes human well-being provides an important constraint. Callicott's claim, then, that human selfinterest is strictly non-normative for Leopold cannot survive scrutiny. ${ }^{59}$

\footnotetext{
${ }^{57}$ Ibid., p. 225.

${ }^{58}$ Ibid., p. 188. Emphasis mine.

${ }^{59}$ By arguing either for Leopold's acknowledgment of distinct human goods and, similarly, for those goods arising relationally with nonhuman constituents of the environment, I am not hereby arguing for
} 
Perhaps, though, Leopold's pluralism is seen most vividly in his characterisations of value conflict and his proposed solutions. Leopold gave consideration as to how conflict amongst his privileged values can reasonably be negotiated. This is important, of course, because circumstances in the world often present dilemmas, forcing one to make hard choices, choices that invariably threaten and often require the sacrificing of valued things, including morally valued things.

In 'The Land Ethic', recall that Leopold defines conservation to be 'a state of harmony between men and land' ${ }^{60}$ Regarding how this conservation-as-harmony comes about, consider Curt Meine's observation that for Leopold, '[c]onflict, paradox, and irony were part of conservation's "authentic human drama;" without them, conservation "falls to the level of a mere Utopian dream"", ${ }^{61}$ It is reasonable to anticipate, then, that the values conservation programs attempt to conserve/preserve involve the conflicts, paradoxes, and ironies from which Leopold contrasts utopianism. Moreover, if my exposition of Leopold's moral views is correct, then Leopold sees a variety of moral value within both humans and the land. Thus, it is the successful negotiation of conflicts, paradoxes, and ironies brought about, at times, by competing moral values that engenders some of the harmony wrought by conservation. Indeed, this idea is present in Leopold's explanation of when it is that conservation efforts may be deemed a success. Recall Leopold's definition of conservation first given in this essay: 'When land does well for its

Leopold to be seen as something akin to an 'enlightened anthropocentrist', as Mark Bryant Budolfson does in a fairly recent article (Budolfson 2014). For my take on what would have to be Leopold's views on the intrinsic value of non-human nature, see Dixon 2016.

${ }^{60}$ Ibid., p. 207.

${ }^{61}$ Meine 1988 , p. 371. 
owner, and the owner does well by his land; when both end up better by reason of their partnership, we have conservation. When one or the other grows poorer, we do not. ${ }^{62}$ Leopoldian conservation along these lines and the negotiation of the kinds of value conflict it invariably involves are illustrated when Leopold writes of practical solutions to environmental problems. For example, in touting a particular solution to the problem of shrinking plant species brought about by human encroachment, Leopold argues that ultimately we can have both 'progress and plants'. He writes in A Sand County Almanac:

The shrinkage in the flora is due to a combination of clean-farming, woodlot grazing, and good roads. Each of these necessary changes of course requires a larger reduction in the acreage available for wild plants, but none of them requires, or benefits by, the erasure of species from whole farms, townships, or counties. There are idle spots on every farm, and every highway is bordered by an idle strip as long as it is; keep cow, plow, and mower out of these idle spots, and the full native flora, plus dozens of interesting stowaways from foreign parts, could be part of the normal environment of every citizen. ${ }^{63}$

Here, then, is an example of conflict negotiation where Leopold clearly sees a way to respect multiple things of moral value. Leopold indicates that farming, grazing, road construction, and the concomitant reduction of land available for wild plants are a necessary means to some human goods (e.g., the moral goods represented by increases in utility for the farmer). He does not think that realising these goods must lead to

\footnotetext{
${ }^{62}$ Leopold, 'The Farmer as Conservationist', p., 238 quoted. in Curt Meine 1988, p. 388.

${ }^{63}$ Leopold 1949, pp. 47-48.
} 
eliminating the plant species from changing landscapes. Border spaces, which farmers already value for reducing erosion from their fields, become spaces specifically reserved for plant species deliberately removed from fields, for example. Leopold's general point is that human goods brought about by some industry need not conflict invariably with the goods represented by the flourishing of nature.

Although Leopold's suggestions as to where plants can find suitable habitat were ecologically creative, his method of conflict resolution in the above example is, from a philosophical point-of-view, rather ordinary. Leopold's strategy acknowledges the goods brought about by humans modifying the land while searching for a way to eliminate any resulting harm to certain values instantiated by the land: he suggests building roads such that they do not come at the expense of species of flora and the ecosystems to which they contribute. A more formal way of stating this conflict-resolution strategy is:

If there is some method $\mathrm{X}$ of realising value $\Phi$ such that $\mathrm{X}$ causes a reduction in another value $\Psi$, one ought to search for an alternative method Y that realises $\Phi$ without also causing a reduction in any other $\Psi$.

Let us call this strategy of Leopold's the Basic Dissolving Strategy. Indeed, it is the kind of conflict dissolving strategy that underlies solutions like that of placing exotic and native plant species along roadsides and within medians or letting those plants subsist on unused portions of a homestead. Of course, for Leopold, conservation is often more hard fought and incremental than to allow for the Basic Dissolving Strategy. For example, conservation efforts may sometimes be spurred not by conscientious private citizens but by robust governmental action, and this can have some negative effects. Leopold writes: 
There is a clear tendency in American conservation to relegate to government all necessary jobs that private landowners fail to perform. Government ownership, operation, subsidy, or regulation is now widely prevalent in forestry, range management, soil and watershed management, park and wilderness conservation, fisheries management, and migratory bird management, with more to come. Most of this growth in governmental conservation is proper and logical, some of it is inevitable. That I imply no disapproval of it is implicit in the fact that I have spent most of my life working for it. ${ }^{64}$

But Leopold could not ultimately be satisfied with government doing everincreasing amounts of conservation work. What comes after the quotation in the text is Leopold questioning, rather ominously, whether greater amounts of governmental participation in conservation may cause this system to collapse under its own weight. Specifically, he questions a government-heavy conservation, asking: 'What is the ultimate magnitude of the enterprise? Will the tax base carry its eventual ramifications? At what point will governmental conservation, like the mastodon, become handicapped by its own dimensions?" ${ }^{65}$ The point here is that although Leopold might think it 'proper and logical' for government to take-up many conservation roles not being assumed by any other entity, he cannot think that the government should take-up all conservation roles. Leopold worries that government resources might be decimated by too heavy a workload.

\footnotetext{
${ }_{65}^{64}$ Leopold, 1949, p. 213.

${ }^{65}$ Ibid.
} 
Leopold also cannot think that many governmental conservation roles should ideally remain the government's in perpetuity for normative reasons; this would be inconsistent with both his stated goals and values. Thus, even if implementing conservation measures via governmental regulation makes the world a better place, as it surely has, the world would be an even better place, ethically, if persons voluntarily took up the mantle of conservation themselves.

Leopold's judgments of FDR's New Deal conservation illustrate the above claims. Curt Meine, explains that Leopold regarded alphabet-program conservation as 'a "natural consequence" of the nation's past abuse of resources, and its mixed success in correcting that abuse'. But Leopold knew all too well that what was needed in terms of true conservation surpassed the government's simply accumulating larger swaths of land (such accumulation being a New Deal mainstay). Leopold recognised, as Meine puts it, that 'resources were everywhere, and so was abuse'. Hence, conservation, for Leopold, needed to be everywhere, and this meant its emerging as a way of life on both public and private lands. ${ }^{66}$ Leopold explains the dynamic:

It is easy to side-step the issue of getting lumbermen to practice forestry, or the farmer to crop game or conserve soil, and to pass these functions to government. But it won't work. I assert this, not as a political opinion, but as a geographical fact. It's not in the cards. The basic problem is to induce the private landowner to conserve on his own land, and no conceivable millions or billions for public land purchase can alter that fact. ${ }^{67}$

\footnotetext{
${ }^{66}$ Meine 1988, p. 320.

${ }^{67}$ Aldo Leopold, Undated Fragment, Leopold Papers 10-6, 16 quoted. in Meine 1988, pp. 320-321.
} 
Meine then adds that there is more than pragmatism doing work in Leopold's thinking here:

This emphasis on individual responsibility was now a firm cornerstone in [Leopold's] philosophical construction. It grew out of his lifetime of conservation field work, but now he was beginning to see it in its larger social context. Private conservation was simply an expression of 'that first theorem of social justice: The Lord helps those who help themselves.' Moreover, to hand the job over to government was to lose many of the rewards and challenges - 'the social disciplines' - formerly reserved for the individual. ${ }^{68}$

As was shown earlier and as is demonstrated here (especially in the last sentence above), Leopold commits himself to the idea that persons ought to be respected as individuals and, what is more, that these persons ought to realise that a source of selfrespect comes from their engaging in right-minded ecological thinking and activity. Put back into the context of New Deal conservation, Meine's point about Leopold appears to be this: Leopold thought New Deal conservation measures are better than an absence of conservation measures altogether, but it is an even greater moral improvement if individuals take action on their own to make conservation more widespread and effective.

For Leopold, then, the adoption of conservation measures by an individual person is character-enhancing in ways that governmental action is not. Yet Leopold concedes that the extent and severity of ecological degradation requires governmental intervention to coerce a coordination sufficiently broad to effect large-scale, systemic restorations. Again, though, even though government has a proper role in broad-scale conservation

\footnotetext{
${ }^{68}$ Meine 1988, p. 321.
} 
projects, especially in correcting past abuses that private citizens are unable/unwilling to remedy, there are responsibilities landowners ought not to shirk. An evolving partnership, therefore, between individuals and government, where individuals become increasingly land-friendly represents—-for Leopold—moral improvement, especially as this partnership enhances the future prospects for persons to engage in right-minded conservation for themselves. Leopold's thinking regarding both New Deal conservation and governmental conservation generally, therefore, represents an additional strategy for dissolving value conflict. This strategy can be given the following formulation:

If there is some method $\mathrm{X}$ of realising value $\Phi$ such that $\mathrm{X}$ causes a reduction in another value $\Psi$, and there is no other alternative method $\mathrm{Y}$ that realises $\Phi$ without also causing a reduction in any other $\Psi$, then $\mathrm{X}$ should be pursued in such a way as to better the possibilities for future, less conflict causing realisations of both $\Phi$ and $\Psi$.

Let us call this conflict negotiating strategy of Leopold's the Long Term Dissolving Strategy. A consistent theme in Leopold's conservation thinking, then, is the rightness of humans dissolving value conflict, whether through creative solutions that dissolve the conflict with no sacrifice of value (i.e., through the Basic Dissolving Strategy) or through a more protracted strategy that betters the position for future value realisations, which reduce the conflict amongst those values hitherto at odds (i.e., through the Long Term Dissolving Strategy). Again, Leopold's example of using roadsides and medians for wild growth areas is an instance of the Basic Dissolving Strategy; his views on New Deal conservation, an example of the Long Term Dissolving Strategy. These are the only decision procedures Leopold's ideas clearly entail other than the land ethic 
principle itself. So, if one wants to derive a complete environmental ethic from Leopold, these need to be present. Moreover, one must invoke multiple notions of the right and the good to make sense of Leopold's commitments, notions of the right and the good that do not appear reducible to one another to yield a monistic theory. Unfortunately for Callicott, he is dismissive of pluralism, generally, ${ }^{69}$ despite its fairly obvious presence in Leopold's writings.

\section{CONCLUSION}

Leopold's land ethic principle goes as follows: 'A thing is right when it tends to preserve the integrity, stability, and beauty of the biotic community. It is wrong when it tends otherwise. ${ }^{70}$ Surely if one reads this moral principle in isolation from the rest of Leopold's ideas, including in isolation from what one finds outside the 'Land Ethic' essay, then she might conclude that Leopold is offering up a moral principle inspired by a monistic theory of value, one that when made explicit is sufficient for guiding all relevant moral conduct. But thinking this is a mistake. Leopold's land ethic principle instead represents an additional (revolutionary!) moral consideration.

This essay has put forward the beginnings of a rather radical interpretation of Leopold's moral ideas, a morally pluralistic one. A pluralistic take on Leopold's views calls into question the most famous interpretations of Leopold put forward by philosopher J. Baird Callicott. Whereas I argue that Leopold both embraces moral pluralism and emphasises a consistency maximisation of values, Callicott first characterised Leopold as

\footnotetext{
${ }^{69}$ See Callicott 2003. A foil for Callicott's critique of pluralism, and an important work in its own right, is Christopher Stone's pluralistic approach put forward in Stone 1988; however, one can also find a shorter essay of Stone's defending pluralism in the same volume as Callicott's 2003 essay: See Stone 2003. A pragmatic approach by Andrew Light that criticises Callicott's indictment of pluralism can also be found in this same volume of collected essays; see Light 2003.

${ }^{70}$ Leopold 1949, pp. 224-225.
} 
exclusively privileging biotic wholes, and then later he backs away from this, arguing that Leopold is best understood within a Humean framework, one that prioritises varying moral communities. However, this last move is based on a monistic theory of value that is not explicitly found in Leopold, and it relegates environmental entities to, by any reasonable estimation, a negligibly efficacious periphery of moral concern. It largely banishes the land ethic from being front-and-center in persons' moral thinking to the margins of persons' moral sentiments and their fluctuations. Given Leopold's stated values and goals, Callicott's move is decidedly un-Leopoldian and cannot be the 'Land Ethic's' moral theoretics. Leopold's explicit views are far more integrative, as they weave in a land ethic with familiar moral concepts. This should not be surprising, as Leopold hoped a land ethic would come to have intellectual currency for quite a varied group: philosophers, the religious, conservationists, and other readers. All of these groups have now heard of a land ethic thanks to Leopold's genius and to the stalwart advocacy of scholars, especially J. Baird Callicott. The hope is that the ideas argued for in this essay go some way toward an even better understanding of what Leopold truly wanted to say, and thus what elements need be present in a theory that emerges from, or is otherwise complementary to, his land ethic. ${ }^{71}$

\footnotetext{
${ }^{71}$ For providing helpful comments, the author thanks Simon Hailwood, Donald Scherer, Jacqueline L. Cowan, and several anonymous referees. Thanks also to conference attendees at the Annual Meeting of the International Society for Environmental Ethics, Allenspark, CO, February 18-21, 2014. Their feedback on material presented there, much of which made its way into this paper, was also of great help.
} 


\section{REFERENCES}

Budolfson, Mark Bryant. 'Why the Standard Interpretation of Aldo Leopold's Land Ethic is Mistaken'. Environmental Ethics 36(4): 443-453.

Callicott, J. Baird. 1987. 'The Conceptual Foundations of the Land Ethic'. In $A$ Companion to a Sand County Almanac: Interpretive and Critical Essays, edited by J. Baird Callicott, 186-217. Madison: Wisconsin UP.

Callicott, J. Baird. 1989. 'Animal Liberation and Environmental Ethics: Back Together Again'. In In Defesne of the Land Ethic: Essays in Environmental Philosophy edited by J. Baird Callicott, 49-59. Albany: SUNY Press.

Callicott, J. Baird. 1995. 'Animal Liberation: A Triangular Affair'. In People, Penguins and Plastic Trees: Basic Issues in Environmental Ethics, edited by Christine Pierce \& Donald VanDeVeer, 237-254. Belmont: Wadsworth.

Callicott, J. Baird. 1998. “"Back Together Again' Again””. Environmental Values 7(4): 61-75.

Callicott, J. Baird. 2003. 'The Case Against Moral Pluralism'. In Environmental Ethics: An Anthology, edited by Andrew Light \& Holmes Rolston III, 203-219. Malden, MA: Blackwell.

Callicott, J. Baird; Grove-Fanning, W., Rowland, J., Gaskind, D., French, R.H., and Walker, K. 2009. 'Was Aldo Leopold a pragmatist?

Rescuing Leopold from the imagination of Bryan Norton'. Environmental Values 18(4): 453-486.

Callicott, J. Baird. 2013 Thinking Like a Planet: The Land Ethic and the Earth Ethic. Oxford: Oxford UP.

Clarke, Melissa. 2014. 'Review of Thinking Like a Planet: The Land Ethic and the Earth Ethic', by J. Baird Callicott. Environmental Ethics 36(3): 365-368.

Dixon, Ben. 2007. 'Darwinism and Human Dignity', Environmental Values. 16 (1): 2342.

Dixon, Ben. 2016. 'Deriving Moral Considerability from Leopold's A Sand County Almanac'. Ethics, Policy \& Environment. 19(2): 196-212.

Holland, Alan. 2016. 'Review of Thinking Like a Planet: The Land Ethic and the Earth 
Ethic', by J. Baird Callicott. Philosophy 91(1): 131-135.

Leopold, Aldo. 1949. A Sand County Almanac and Sketches Here and There. New York: Oxford University Press.

Leopold, Aldo. 1988. 'The Farmer as Conservationist'. American Forests 45(6) (June 1939). Meine, Curt. Aldo Leopold: His Life and Work. Madison: University of Wisconsin Press.

Light, Andrew. 2003. 'The Case for a Practical Pluralism'. In Environmental Ethics: An Anthology, edited by Andrew Light \& Holmes Rolston III, 229-247. Malden, MA: Blackwell.

Meine, Curt. 1988. Aldo Leopold: His Life and Work. Madison: The University of Wisconsin Press.

Millstein, Roberta L. 2015. 'Re-Examining the Darwinian Basis for Aldo Leopold's Land Ethic', Ethics, Policy \& Environment 18(3): 301-317.

Norton, Bryan G. 2011. 'What Leopold Learned from Darwin and Hadley: Comment on Callicot et al'. Environmental Values 20(1): 7-16.

Ouderkirk, Wayne. 2002. 'Introduction'. In Land, Value, Community: Callicott and Environmental Philosophy, edited by Wayne Ouderkirk and Jim Hill, 1. Albany: SUNY Press.

Pojman, Louis P. 2001. Environmental Ethics: Readings in Theory and Applications. 3rd. Stamford, CT: Wadsworth.

Popper, Karl R. 1963. 'Plato as Enemy of the Open Society'. In Plato: Totalitarian or Democrat?, edited by Thomas Landon Thorson, 41-102. Englewood-Cliffs: Prentice-Hall.

Regan, Tom. 1983. The Case for Animal Rights. Berkeley: University of California Press.

Rolston III, Holmes. 2012. A New Environmental Ethics: The Next Millennium for Life on Earth. New York: Routledge.

Sober, Elliott. 2003. 'Philosophical Problems for Environmentalism'. In Foundations of Environmental Philosophy: A Text with Readings, edited by Frederik A. Kaufman. New York: McGraw-Hill.

Stone, Christopher. 1988. Earth and Other Ethics: The Case for Moral Pluralism. New York: HarperCollins.

Stone, Christopher. 2003. 'Moral Pluralism and the Course of Environmental Ethics'. In 
Environmental Ethics: An Anthology, edited by Andrew Light \& Holmes Rolston III, 193-202. Malden, MA: Blackwell.

Timmons, Mark. 2002. Moral Theory: An Introduction. Elements of Philosophy Series. Lanham: Rowman \& Littlefield.

Varner, Gary. 2003. 'Sentientism'. In A Companion to Environmental Philosophy, edited by Dale Jamieson, 196. Malden, MA: Blackwell. 